\title{
Effects of formulating diets with digestible amino acids and enzyme supplementation on the chemical composition of breast muscles in two broiler genotypes
}

\author{
W. Szczurek \\ National Research Institute of Animal Production, \\ Department of Animal Nutrition and Feed Science \\ 32-083 Balice, Poland
}

(Received 30 July 2007; revised version 3 December 2007; accepted 8 April 2008)

\begin{abstract}
The experiment was carried out on ISA 215 and Ross 308 broilers. Within each genotype, two hundred 21-day-old chickens were allocated to 4 groups of 50 birds ( 5 replicates of 5 males and 5 females per group). From days 22 to 42 of life the birds of both crosses were given two barley-based diets containing a high proportion of rapeseed meal and a mix of legume seeds. The formulation of the diet was based on total (TAA) or digestible amino acids (DAA), and diets were prepared with or without supplementing a commercial enzyme preparation containing $\beta$-glucanase, cellulase, xylanase, $\alpha$-amylase and protease.

Compared with ISA, Ross birds had lower $(\mathrm{P}<0.01)$ body weight $(\mathrm{BW})$ gains, but greater breast muscle yield ( 151 vs $162 \mathrm{~g} / \mathrm{kg} \mathrm{BW;} \mathrm{P}<0.01)$ and lower fat content in this muscle $(10.6 \mathrm{vs} 9.9 \mathrm{~g} / \mathrm{kg}$; $\mathrm{P}<0.01)$. In ISA broilers, there was an increase in the level of muscle fat in the birds receiving the DAA diet. The significant interaction showed that the level of C18:0 acid increased in ISA females fed the DAA diet. The enzyme supplement increased $(\mathrm{P} \leq 0.05)$ the crude protein $(\mathrm{CP})$ content and reduced $(\mathrm{P} \leq 0.01)$ the proportion of fat in ISA broilers (particularly in females; $\mathrm{P}<0.05$ ). The muscle lipids of ISA chickens fed the enzyme-supplemented diet contained more C18:1 (particularly males; $\mathrm{P}<0.05)$ and total monounsaturated FA $(\mathrm{P} \leq 0.01)$. Ross chickens responded to the formulation based on DAA with an increase in the CP and dry matter content in the breast muscle $(\mathrm{P} \leq 0.01)$. The tendency towards reduced fat levels in the Ross birds fed the DAA diet was significant for females (interaction; $\mathrm{P}<0.05)$. In contrast to ISA, in Ross birds added enzymes did not significantly affect the proportions of the analysed muscle components.
\end{abstract}

KEY WORDS: digestible amino acids, feed enzymes, breast muscle, chemical composition, genotype, broiler chickens

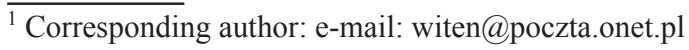




\section{INTRODUCTION}

Nutritional factors play an important role in modifying the chemical composition of chicken meat and its value as a food product, which is determined mainly by the quantitative and qualitative proportion of lipids (Mieczkowska and Smulikowska, 2005). It has also been shown that the deposition of breast muscles, the most valuable part of chicken meat, and the level of chemical components in these muscles vary according to bird genotype and sex (Gornowicz and Dziadek, 2001).

In an effort to maximize the use of amino acids (AA) for muscle formation in broiler chickens it is particularly important that the levels of AA in diets be formulated precisely with regard to their availability from individual feed ingredients. In evaluating availability of a protein-bound AA, determining the degree to which it is released from feedstuffs is of special importance. By taking account of only that portion of the total amount of an amino acid (TAA) that has been digested, it is possible to predict with a high probability the amount of AA that will be in a form suitable for absorption and utilization for tissue anabolism. Some earlier studies showed that the use of digestible amino acid (DAA) values in the formulation of diets containing sources of amino acids that are less well digested than those in soyabean meal (e.g., rapeseed meal, peas or faba beans) has a favourable effect on the quality of broiler carcasses in terms of increased muscling and reduced fatness (Perttilä et al., 2002; Szczurek, 2003b). No reports have revealed whether, and to what extent, formulation based on DAA values affects the chemical composition of muscles, especially when chickens are fed diets rich in components of lower AA digestibility. In an earlier study from our laboratory, feeding broilers during days 22-42 of age diets formulated according to the content of digestible AA in feed ingredients improved utilization of dietary nitrogen (Szczurek, 2003a). It was therefore assumed that the amount of crude protein $(\mathrm{N} \times 6.25)$ deposited in chicken muscles may vary depending on the amino acid system used to formulate the composition of the grower diet.

The use of different combinations of carbohydrase enzymes ( $\beta$-glucanase, cellulase, xylanase, hemicellulase and $\alpha$-amylase) in barley- and/or wheat-based diets containing such ingredients as lupins or peas and rape seed products, significantly improves the degradation of non-starch polysaccharides (NSP) and the digestibility of starch, crude protein and amino acids in broilers (Cowieson et al., 2003; Meng et al., 2005; Orda et al., 2006). Considering this, it seems possible to expect some changes in the levels of protein, fat and/or mineral components in chicken meat when birds are fed enzyme-supplemented diets. Therefore, it is surprising that there are few reports in the literature demonstrating the effects of feed enzymes on the retention of basic chemical constituents in broiler muscles. Because of interactions between diet ingredients, different enzymatic activities 
of preparations used, and the sex of birds, prior research has produced inconclusive results. Kondzielska and Pisarski (2000) showed a significant reduction in intramuscular fat content in breast muscles after supplementation of barley-based diets with $\beta$-glucanase. Wojnowska and Gornowicz (2006) reported that the use of xylanase from Bacillus subtilis in a wheat-and-maize-based diet brought about a significant increase in fat content and a tendency towards increased crude protein retention.

Based on data obtained in an experiment with chickens representing two commercial broiler crosses, the presented work aimed at determining and comparing changes in the proportions of basic chemical constituents and composition of fatty acids in the breast muscles as caused by formulation of multi-ingredient diets on the basis of total or digestible amino acids and by supplementation of these diets with an enzyme complex (primarily carbohydrases). Within each genotype, sex interactions were used to evaluate the reaction of chickens to the dietary factors applied.

\section{MATERIAL AND METHODS}

The study protocol and bird handling procedures were reviewed and approved by the Local Ethics Committee for Animal Experimentation.

\section{Diets and animals}

Using locally grown cereals and plant protein sources, two grower-type diets were formulated to contain high proportions of barley, rapeseed meal and legume seeds (Table 1).

In the TAA diet, the levels of total amino acids followed values suggested in Poultry Feeding Standards (1996). The digestible amino acids (DAA) diet was formulated to reach the values obtained by converting TAA levels into DAA levels using the methodology and estimates proposed by Dalibard and Paillard (1995). Averaged true faecal digestibility coefficients derived from tables issued by RhonePoulenc (1993) and Ajinomoto Heartland LLC (www.lysine.com/new/tecpoul2. $\mathrm{htm}$ ) were used to calculate the DAA contents in individual feed ingredients.

Each diet was prepared with or without an enzyme preparation $(1 \mathrm{~g} / \mathrm{kg}$ on top of feed). According to the manufacturer's specification (Hameco Agro B.V.) the preparation contained: $\beta$-glucanase, 400 ; cellulase, 600 ; xylanase, $400 ; \alpha$-amylase, 15; protease, 14 units/g.

The concurrent introduction of different protein sources enabled the experimental diets to be formulated with high accuracy according to the levels of 9 essential amino acids while avoiding excessive amounts of some AA and the need 
Table 1. Composition of experimental grower diet formulated on a total (TAA) or digestible (DAA) amino acid basis, $\mathrm{g} / \mathrm{kg}$

\begin{tabular}{|c|c|c|}
\hline \multirow{2}{*}{ Item } & \multicolumn{2}{|c|}{ Diet } \\
\hline & TAA & DAA \\
\hline \multicolumn{3}{|l|}{ Feed ingredients } \\
\hline barley $(10.9 \% \mathrm{CP})$ & 321.2 & 316.1 \\
\hline maize $(9.7 \% \mathrm{CP})$ & 130.0 & 130.0 \\
\hline rapeseed meal $(34.0 \% \mathrm{CP})$ & 150.0 & 150.0 \\
\hline field pea seeds var. Piast $(19.0 \% \mathrm{CP})$ & 150.0 & 150.0 \\
\hline lupin seeds var. Polonez $(31.1 \% \mathrm{CP})$ & 60.0 & 60.0 \\
\hline faba beans var. Nadwiślański (26.2\% CP) & 60.0 & 50.0 \\
\hline soyabean meal $(45.5 \% \mathrm{CP})$ & 5.0 & 20.0 \\
\hline DL-methionine $(99 \%)$ & 1.8 & 1.9 \\
\hline constant components ${ }^{1}$ & 122.0 & 122.0 \\
\hline \multicolumn{3}{|l|}{ Calculated or analysed } \\
\hline metabolizable energy, $\mathrm{MJ} / \mathrm{kg}^{2}$ & 12.23 & 12.22 \\
\hline crude protein $^{2}$ & 164.80 & 168.30 \\
\hline $\mathrm{Ca}^{3}$ & 9.70 & 9.70 \\
\hline P available ${ }^{3}$ & 4.40 & 4.40 \\
\hline \multicolumn{3}{|l|}{ Amino acids ${ }^{4}$} \\
\hline \multicolumn{3}{|l|}{ total } \\
\hline lysine & 9.6 & 9.8 \\
\hline methionine & 4.3 & 4.4 \\
\hline methionine + cystine & 7.8 & 8.0 \\
\hline tryptophan & 1.8 & 1.9 \\
\hline threonine & 6.7 & 6.9 \\
\hline arginine & 10.2 & 11.7 \\
\hline valine & 8.3 & 8.8 \\
\hline leucine & 13.2 & 13.9 \\
\hline isoleucine & 7.1 & 7.7 \\
\hline \multicolumn{3}{|l|}{ digestible } \\
\hline lysine & 8.0 & 8.2 \\
\hline methionine & 3.9 & 4.0 \\
\hline methionine + cystine & 6.5 & 6.8 \\
\hline tryptophan & 1.5 & 1.6 \\
\hline threonine & 5.5 & 5.7 \\
\hline arginine & 8.9 & 9.2 \\
\hline valine & 6.7 & 7.0 \\
\hline leucine & 11.7 & 12.0 \\
\hline isoleucine & 5.9 & 6.3 \\
\hline
\end{tabular}

${ }^{1}$ constant components, g/kg: rape seed oil 42, lard 42, dicalcium phosphate 20 , limestone $10, \mathrm{NaCl} 3$ and trace minerals-vitamin premix 5 (provided per kg of diet, mg: retinyl palmitate 6.6, cholecalciferol 0.08 , dl- $\alpha$-tocopheryl acetate 40 , menadion 2.25 , thiamin 2.0 , riboflavin 7.25 , pyridoxine 4.25 , cyanocobalamine 0.03 , biotin 0.1 , folic acid 1.0 , nicotinic acid 40 , calcium pantothenate 12 , choline chloride 450, Fe 65, Zn 65, Mn 100, Cu 15, I 0.8, Se 0.25, Co 0.4, monensin sodium 100)

${ }^{2}$ calculated on the basis of chemical analysis of feed ingredients, energy value - using formulas of The European Table of Energy Values for Poultry Feedstuffs, 1989. 3rd Edition (WPSA, Wageningen)

${ }^{3}$ calculated according to the data given in Poultry Feeding Standards (1996)

${ }^{4}$ total amino acid values (TAA) are analysed, digestible amino acid values (DAA) are calculated on the basis of analysed amino acid composition of raw feedstuffs 
to use crystalline L-valine, L-leucine and L-isoleucine. Both diets were supplemented with feed-grade crystalline DL-methionine considered $100 \%$ digestible. An exchange efficiency of $81.2 \%$ was also assumed for the use of DL-methionine to equalize total and digestible cystine content. The level of the other AA was adjusted by differentiating the proportions of soyabean meal and faba beans. The crude protein content, determined by the assumed amount of essential AA, and the proportion of dietary energy, were defined as the sum of the levels of particular ingredients. The calculated energy value of the diets was lower than that usually recommended for broilers older than 3 weeks, which provided an extra opportunity to improve energy utilization using enzymes.

One-day-old chickens of two commercial crosses: ISA 215 and Ross 308. (preliminary amount 240 per cross, sex ratio 1:1) with an average body weight of 39 and $38 \mathrm{~g}$, respectively, were obtained from local hatcheries. The birds were raised in battery brooders under the same environmental conditions. Over the first 3 weeks, the chicks were fed ad libitum a maize-wheat-soyabean meal starter diet (12.85 MJ ME, $196 \mathrm{~g}$ crude protein, $11.5 \mathrm{~g}$ lysine, $8.3 \mathrm{~g}$ met + cys, $7.4 \mathrm{~g}$ threonine, $2.5 \mathrm{~g}$ total tryptophan per $\mathrm{kg}$ ).

On day 21 of age, the chickens were weighed and birds with extreme body weights rejected. Birds selected for the experiment (200 ISA and 200 Ross broilers) were randomly allocated to experimental groups (50 birds per group) and placed in $87 \times 90 \times 37 \mathrm{~cm}$ wire cages. Within each genotype, four groups with 5 replicates (cages) of 5 males +5 females were formed. From days 22 to 42 of age, chickens of both genotypes were fed experimental diets provided in mash form. Birds had free access to feed and water. During the experiment the temperature in the broiler house was maintained at $21^{\circ} \mathrm{C}$ and the lighting cycle was $20 \mathrm{~h}$ light: $4 \mathrm{~h}$ dark.

\section{Experimental procedures}

Body weight, feed intake and mortality were monitored throughout the experiment. At the end of the experiment, ten birds ( 5 females and 5 males with live body weights close to the group average) were chosen from each feeding group within a genotype and used for slaughter analysis. The birds were fasted $12 \mathrm{~h}$, weighed and slaughtered by cervical dislocation. Carcasses were cooled overnight at $4^{\circ} \mathrm{C}$ and weighed. The breast muscles (M. pectoralis major) were excised, weighed and homogenized. After the samples were taken to determine dry matter, the homogenates were stored at $-20^{\circ} \mathrm{C}$ for later analyses.

\section{Chemical analyses}

The basic chemical composition of the feed materials and breast muscles was determined according to AOAC (1990). The samples of feed were hydrolysed in 6 
$N \mathrm{HCl}$ at $110^{\circ} \mathrm{C}$ for $22 \mathrm{~h}$ for amino acid analyses. For determination of methionine and cystine, preliminary oxidation with performic acid was carried out. Tryptophan was assayed following alkaline hydrolysis of samples in a barium hydroxide solution $\left(110^{\circ} \mathrm{C}, 18 \mathrm{~h}\right)$. All amino acids were determined by HPLC using a Beckman 126AA System Gold analyser.

The fatty acid content of muscle lipids was analysed after extraction of samples according to Folch et al. (1957). Esters of fatty acids were determined using a Varian 3400 gas chromatograph with a CP-WAX 58 column, an 8200CX autosampler and Varian Star 4.5 software.

\section{Statistical analysis}

The results were subjected to analysis of variance using the Statistica 5.1 computer package (www.statsoft.pl). The effects of feed formulation method (TAA vs DAA), enzyme supplementation of diets (no enzymes vs with enzymes) and sex on the chemical parameters of breast muscles were analysed separately for both genotypes in a three-factorial design and the significance of the main effects and interactions was determined. Differences between ISA and Ross broilers, in growth, some slaughter indices and chemical composition of breast muscles, were tested using the pooled t-test.

\section{RESULTS}

Significant differences in body weight gains (BWG) associated with the genotype of chickens (ISA>Ross) were found as early as at 21 days of age, after the preliminary phase of feeding. Comparative analysis of the data for both sexes (Table 2) showed that ISA birds also had significantly higher daily BWG than Ross chickens during the experiment (days 22 to 42). Ross broilers had a similar dressing percentage to ISA birds but greater $(\mathrm{P}<0.01)$ breast muscle yield per $\mathrm{kg}$ live body weight at slaughter. Compared with ISA, the muscles of Ross chickens contained on average less $(\mathrm{P}<0.01)$ crude fat $(\mathrm{CF})$ and similar amounts of dry matter (DM), crude protein (CP) and ash (CA), and total saturated (SFA), monounsaturated (MUFA) and polyunsaturated (PUFA) fatty acids in the lipids of the analysed tissue.

In the chickens of ISA genotype (Table 3 ), especially in females $(\mathrm{AA} \times \mathrm{S}$; $\mathrm{P}<0.05$ ), the method of diet formulation (TAA vs DAA) resulted in an increased proportion of $\mathrm{CF}$ in the muscles of birds receiving the DAA diet. The use of this diet did not significantly affect the mean levels of other basic components or the proportions of the major fatty acids in the muscle lipids of ISA broilers of either sex. However, the AA $\times \mathrm{S}$ interaction $(\mathrm{P}<0.05)$ showed a clear increase in the 
Table 2. The comparison of some growth and post-slaughter parameters and chemical composition of breast muscles of broilers used in the experiment (overall means for both sexes)

\begin{tabular}{lccc}
\hline Parameter & ISA 215 & Ross 308 & SEM \\
\hline Initial (day 21) body weight, g & $638^{\mathrm{A}}$ & $559^{\mathrm{B}}$ & 6.7 \\
Daily weight gain during experiment, g & $75.7^{\mathrm{A}}$ & $66.7^{\mathrm{B}}$ & 0.9 \\
Dressing percentage, \% of live body weight & 74.4 & 74.2 & 0.2 \\
Breast muscle yield, g/kg live body weight & $151^{\mathrm{A}}$ & $162^{\mathrm{B}}$ & 1.6
\end{tabular}

Basic chemical constituents of breast muscle, $\mathrm{g} / \mathrm{kg}$ of raw tissue

$\begin{array}{lccc}\text { dry matter } & 259 & 258 & 0.5 \\ \text { crude protein } & 237 & 237 & 0.5 \\ \text { crude fat } & 11.2^{\mathrm{A}} & 9.9^{\mathrm{B}} & 0.2 \\ \text { crude ash } & 10.6 & 11.1 & 0.1\end{array}$

Fatty acids ${ }^{1}$ in muscle lipid, $\mathrm{mg} / \mathrm{g}$ of total fatty acids

\begin{tabular}{llll}
$\sum$ SFA & 336 & 341 & 2.5 \\
$\sum$ MUFA & 373 & 369 & 3.7 \\
$\sum$ PUFA & 290 & 289 & 2.7 \\
\hline
\end{tabular}

1 SFA - saturated fatty acids (C14:0 + C16:0 + C18:0)

MUFA - monounsaturated fatty acids (C16:1 + C18:1)

PUFA - polyunsaturated fatty acids (C18:2 + C18:3 + C20:4 + C20:5 + C22:6)

$\mathrm{A}, \mathrm{B}$ means in a row with different superscripts are significantly different at $\mathrm{P}<0.01$

level of C18:0 acid in females receiving the DAA diet. Ross chickens (Table 4), both males and females, responded to the formulation based on DAA values with a significant $(\mathrm{P} \leq 0.01)$ increase in the proportion of $\mathrm{DM}$ and $\mathrm{CP}$ and a decrease in the fat-to-protein ratio $(\mathrm{P} \leq 0.05)$. The tendency towards a reduced level of $\mathrm{CF}$ in the muscles of Ross birds fed the DAA diet was confirmed statistically in females $(\mathrm{AA} \times \mathrm{S} ; \mathrm{P}<0.05)$.

The enzyme supplement increased the proportion of $\mathrm{CP}(\mathrm{P} \leq 0.05)$ and reduced the proportion of $\mathrm{CF}(\mathrm{P} \leq 0.01)$ in the muscles of ISA chickens (Table 3$)$. The fatto-protein ratio was also decreased. The reduction in fat content was particularly evident in females $(\mathrm{E} \times \mathrm{S} ; \mathrm{P}<0.05)$. The muscle lipids of ISA chickens receiving enzyme-supplemented diets contained significantly more C18:1 acid and total MUFA. The level of $\mathrm{C} 18: 1$ acid underwent substantial modification in males $(\mathrm{E} \times \mathrm{S} ; \mathrm{P}<0.05)$. In Ross broilers (Table 4$)$, the enzymes used did not significantly affect the proportions of the analysed chemical components in breast muscles. No enzyme supplement $\times$ sex interaction was found in the birds of this genotype. 


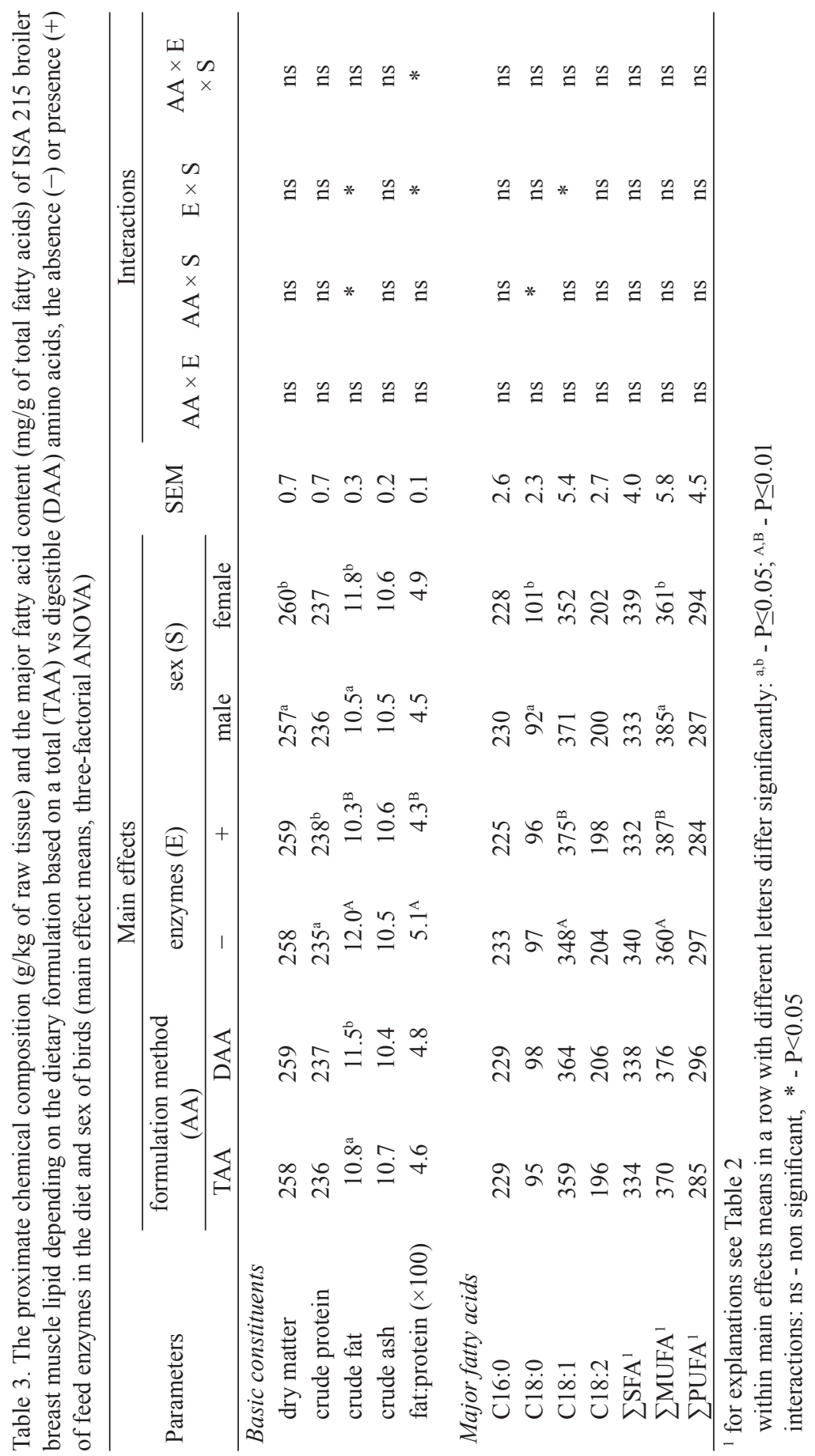




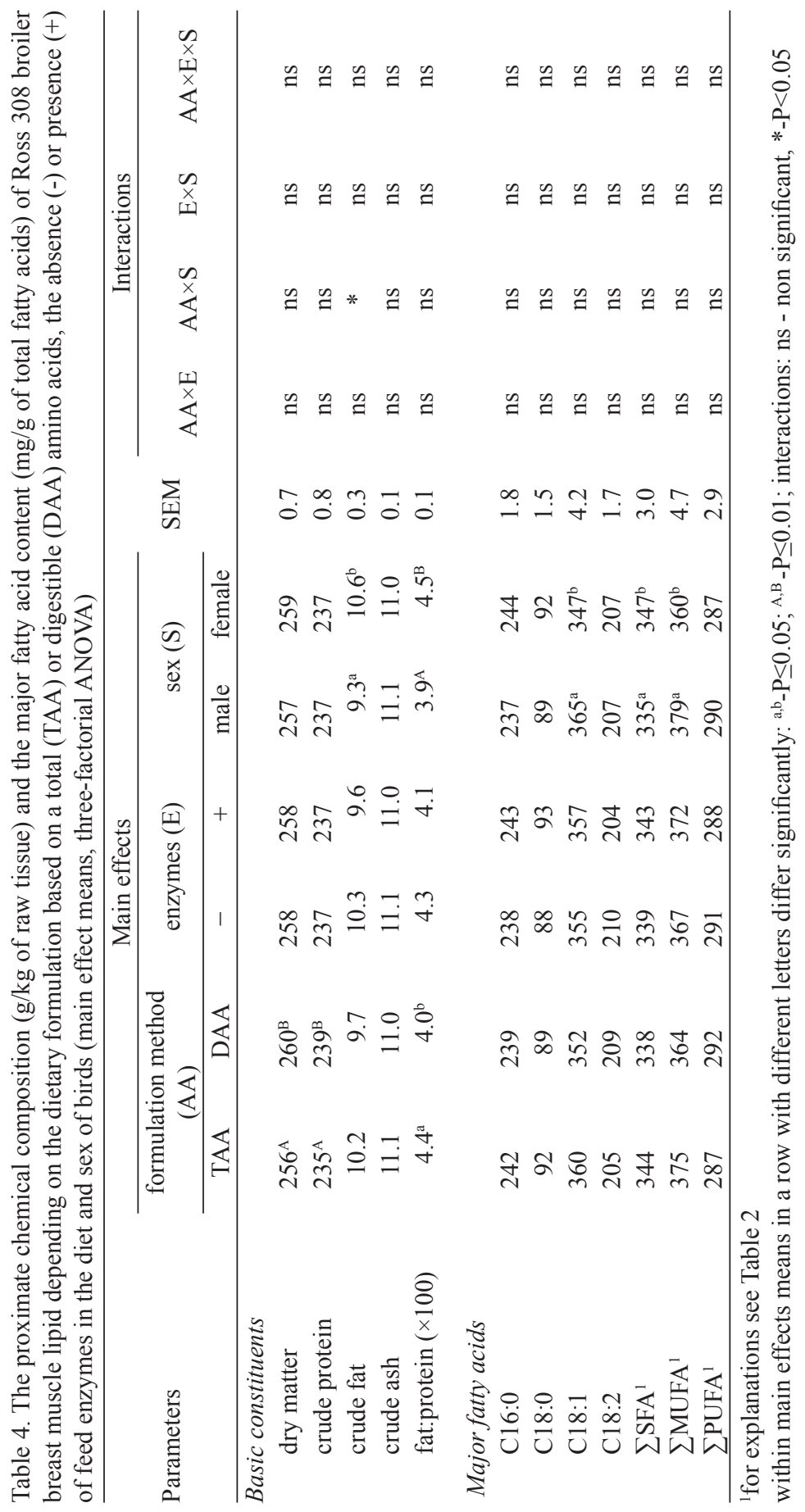




\section{DISCUSSION}

The results of many experiments testing the productive value of broilers show that ISA 215 birds are characterized by a high rate of growth, while Ross 308 chickens have a high breast muscle-to-body weight ratio. As expected, the yield of breast muscles $(\mathrm{BM})$ in relation to live body weight was higher in Ross than in ISA broilers. The results of comparative studies indicate that BM yield is determined by the increased dimensions of muscle fibres and this trait is significantly correlated with the total amount of muscle fibres found in BM (Scheuermann et al., 2004). The genotype-related significant differences in the levels of basic chemical components in BM concerned the level of lipids (ISA > Ross). These observations are consistent with the findings of Gornowicz and Dziadek (2001) and support their classification of the commercial crosses of broiler chickens used in Poland into groups with a higher (including ISA 215) and lower (including Ross 308) proportion of crude fat in BM.

The diets used in the experiment contained major protein components for which the values of AA digestibility and bioavailability do not differ markedly (Parsons, 1996). Although some discrepancies between the actual and calculated (using published coefficients) amounts of digestible AA cannot be excluded, this allows the conclusion that the supply level of AA available to chickens for tissue synthesis was higher in the DAA diet. An indirect confirmation of this conjecture was the significant AA $\times \mathrm{S}$ interaction found in Ross females, indicating a decrease in the proportion of fat in BM when the DAA diet was fed. Many studies have shown that an increased AA-to-energy ratio in the diet reduces fat deposition in the bodies of chickens. Unlike in ISA chickens, the significant modifications in the analysed chemical parameters of Ross male and female muscles observed under the influence of the formulation method also included an increased level of CP. This resulted in an increase in DM content when the diet formulated according to digestible AA was used. This effect was comparable with the beneficial impact of the increasing AA supply on crude protein retention in the bodies of growing chickens (Eits et al., 2002). The fact that a similar phenomenon did not occur in ISA chickens is no surprise in the light of the study by Tesseraud et al. (2001). These authors showed that genetic factors modify $\mathrm{CP}$ metabolism and retention in the $\mathrm{BM}$ of chickens, whereas broilers characterized by a high yield of these muscles are more sensitive to changes in the supply of AA, lysine in particular.

Unlike in Ross, feeding a diet formulated on DAA basis increased the level of lipids in the muscles of ISA females, especially stearic acid $(\mathrm{AA} \times \mathrm{S}$ interaction; Table 3). Assuming that the amount of AA available to chickens was higher when the DAA diet was fed and considering that, depending on the performance parameter, the AA requirements of females are usually lower compared with males (Garcia et al., 2006; Lumpkins et al., 2007), the above relationship could result 
from the increased retention of fat derived from endogenous synthesis. It may be speculated that this fat could form during liponeogenesis from carbon residues of AA that were overabundant in relation to the needs of the birds of this sex. The lack of a similar reaction in Ross females can be linked to the higher nutrient requirements of Ross broilers compared with the amount of nutrients, including both forms of AA supplied in the feed. This was confirmed when the performance parameters of both chicken genotypes were compared in an earlier paper (Szczurek, 2004).

The genotype of birds was a factor that determined changes in the chemical composition of muscles under the influence of the enzyme supplement. In ISA broilers, supplementation of diets with enzymes reduced the amount of CF, especially in females $(\mathrm{E} \times \mathrm{S}$ interaction). A similar reaction to a multi-enzyme supplement in Starbro females (with higher fatness than males) was reported by Kondzielska and Pisarski (2000) who used barley diets supplemented with a mixture of vegetable oil and lard. In the case of Ross birds, with the same sex-related differences in CF level as those in ISA, the effect of supplemental enzymes was not significant. Improvements in fat digestibility and retention in the presence of exogenous carbohydrases were reported for Starbro males (Smulikowska and Mieczkowska, 1996). Therefore it seems that with a certain composition and the high level of fat in the experimental diets, the different reactions of birds of the same sex to the enzyme preparation used were determined by genotype. Differences resulting from bird genotype were also noticeable in the reaction of birds to the enzyme supplement with regard to CP content. Only ISA chickens responded to the diminishing of the adverse effect of water-soluble and insoluble NSP by enzymes (e.g., $\beta$-glucans derived from barley or cellulose from rapeseed meal) and the expected increase in the pool of AA absorbed from the small intestine. This was likely due to the increased retention of protein in the rapidly increasing body weight of these birds, in response to the higher supply and/or favourable changes in the proportion of AA reaching the blood stream (Tesseraud et al., 2001). It is worth noting that some authors observed a significant improvement in the retention of nitrogen compounds in broiler carcasses under the influence of the enzyme complex (cellulase, xylanase, $\alpha$-amylase) added to a wheat-based diet with a high proportion of peas (Cowieson et al., 2003). The increased total MUFA (significant in ISA broilers) resulted from the increased proportion of oleic acid. Assuming an improvement in nutrient absorption conditions in the small intestine in the presence of NSP-degrading enzymes, this was possibly related to the better utilization of lupin seed fat, which is rich in this acid (Mieczkowska and Smulikowska, 2005). The increased de novo synthesis of C18:1 acid due to the raised supply of energetic substrates (glucose) and activity of cellular desaturase cannot be ruled out. This increase could result from the activity of the preparation's exogenous amylase, which assists the hydrolysis of starch derived from barley and maize. 
The present results showed an inconsistent reaction of broiler chickens of two commercial genotypes to the systems of amino acid balancing and enzyme supplementation used in a low-energy grower diet based on barley and containing rapeseed meal and a mix of legume seeds as the main protein sources. Ross 308 broilers, characterized by greater breast muscle yield, reacted to diet formulation with digestible amino acid values with an increase in the crude protein and dry matter content of muscles. In ISA 215 chickens, with a lower yield of these muscles, the fat content increased. Faster-growing ISA broilers responded to the multi-enzyme supplement with increased deposition of crude protein and a reduced level of fat in the analysed tissue. The different reactions to the formulation with total or digestible amino acids and enzyme supplementation, with regard to the crude fat content of breast muscles and the proportion of oleic and stearic acids in this fat, could result from differences in the needs for amino acids associated with the sex and origin of the experimental birds.

The above relationships concerning the evaluated nutritional factors can be used in modelling the chemical composition, and thus the technological quality and dietetic value of the meat of broiler chickens representing different genotypes.

\section{ACKNOWLEDGEMENTS}

Thanks are due to Prof. Jerzy Koreleski for providing the opportunity to discuss the problems presented in this paper.

\section{REFERENCES}

AOAC, 1990. Association of Official Analytical Chemists, Official Methods of Analysis. 15th Edition. Arlington, VA

Cowieson A.J., Acamovic T., Bedford M.R., 2003. Supplementation of diets containing pea meal with exogenous enzymes: effect on weight gain, feed conversion, nutrient digestibility and gross morphology of the gastrointestinal tract of growing broiler chicks. Brit. Poultry Sci. 44, 427-437

Dalibard P., Paillard E., 1995. Use of the digestible amino acid concept in formulating diets for poultry. Anim. Feed Sci. Tech. 53, 189-204

Eits R.M., Kwakkel R.P., Verstegen M.W.A., Stoutjesdijk P., De Greff K.H., 2002. Protein and lipid deposition rates in male broiler chickens: separate responses to amino acids and protein-free energy. Poultry Sci. 81, 472-480

Folch J., Lees M., Stanley G.H.S., 1957. A simple method for the isolation and purification of total lipids from animal tissues. J. Biol. Chem. 226, 497-509

Garcia A.R., Batal A.B., Baker D.H., 2006. Variations in the digestible lysine requirements of broiler chickens due to sex, performance parameters, rearing environment, and processing yield characteristics. Poultry Sci. 85, 498-504

Gornowicz E., Dziadek K., 2001. Variability in chemical composition of breast and thigh muscles depending on the origin of broiler chickens (in Polish). Rocz. Nauk. Zoot. 28, 89-100 


\section{DIGESTIBLE AMINO ACIDS, ENZYMES AND MUSCLE COMPOSITION}

Kondzielska L., Pisarski R.K., 2000. The effect of enzymatic preparations on chemical composition of chicken's breast muscle (in Polish). Ann. Anim. Sci. 27, 219-230

Lumpkins B.S., Batal A.B., Baker D.H., 2007. Variations in the digestible sulfur amino acid requirement of broiler chickens due to sex, growth criteria, rearing environment, and processing yield charactetristics. Poultry Sci. 86, 325-330

Meng X., Slominski B.A., Nyachoti C.M., Campbell L.D., Guenter W., 2005. Degradation of cell wall polysaccharides by combinations of carbohydrase enzymes and their effect on nutrient utilization and broiler chicken performance. Poultry Sci. 84, 37-47

Mieczkowska A., Smulikowska S., 2005. The influence of white lupin seeds in diets supplemented with fats of animal or plant origin on the fatty acid composition of broiler tissues. J. Anim. Feed Sci. 14, 93-107

Orda J., Jamroz D., Wiliczkiewicz A., Wertelecki T., Skorupińska J., Broz J., 2006. Effects of increased dietary inclusion of yellow lupins and enzyme supplementation on performance, ileal digestibility of nutrients and microbial status of large intestine in broiler chickens. Arch. Geflügelk. 70, 14-21

Parsons C.M., 1996. Digestible amino acids for poultry and swine. Anim. Feed Sci. Tech. 59, 147153

Perttilä S., Valaja J., Partanen K., Jalava T., Vanäläinen E., 2002. Apparent ileal digestibility of amino acids in protein feedstuffs and diet formulation based on total vs digestible lysine for poultry. Anim. Feed Sci. Tech. 98, 203-218

Poultry Feeding Standards. Recommended Allowances and Nutritive Value of Feedstuffs (in Polish), 1996. S. Smulikowska (Editor). 3rd Edition. The Kielanowski Institute of Animal Physiology and Nutrition, Polish Academy of Sciences. Jabłonna (Poland), pp. 45-50

Rhone-Poulenc, 1993. Rhodimet Nutrition Guide. Feed Ingredients Formulation in Digestible Amino Acids. 2nd Edition. Rhone-Poulenc Animal Nutrition, Antony Cedex (France)

Scheuermann G.N., Bilgili S.F., Tuzun S., Mulvaney D.R., 2004. Comparison of chicken genotypes: myofiber number in pectoralis muscle and myostatin ontogeny. Poultry Sci. 83, 1404-1412

Smulikowska S., Mieczkowska A., 1996. Effect of rye level, fat source and enzyme supplementation on fat utilization, diet metabolizable energy, intestinal viscosity and performance of broiler chickens. J. Anim. Feed Sci. 5, 379-393

Szczurek W., 2003a. A note on the performance and nitrogen output of broiler chickens fed diets with and without meat-and-bone meal formulated to total or digestible amino acid requirements. J. Anim. Feed Sci. 12, 813-819

Szczurek W., 2003b. The potential for the improvement of meat yields of broilers by formulating diets containing plant protein sources on a digestible amino acid basis. Ann. Anim. Sci., Suppl. $2,231-235$

Szczurek W., 2004. Effect of feed formulation with total versus digestible amino acids and enzyme supplementation on the performance of broilers of different genotypes (in Polish). Rocz. Nauk. Zoot., Suppl. 20, 267-271

Tesseraud S., Temim S., Le Bihan-Duval, Chagneau A.M., 2001. Increased responsiveness to dietary lysine deficiency of pectoralis major muscle protein turnover in broilers selected on breast development. J. Anim. Sci. 79, 927-933

Wojnowska M., Gornowicz E., 2006. Effects of feed enzymes in broiler chicken diet on the physicochemical traits of breast muscles. Anim. Sci., Suppl. 1, 56-57 